\title{
Aspectos indicativos de envelhecimento facial precoce em respiradores orais adultos $* * * * *$
}

\author{
Indicative factors of early facial aging in mouth breathing adults
}

\author{
Aline Cabral de Oliveira* \\ César Antônio Lira dos Anjos** \\ Érika Henriques de Araújo Alves da Silva*** \\ Pedro de Lemos Menezes****
}

*Fonoaudióloga. Endereço para correspondência: Rua Antonio Viera Filho 30 - quadra 08 - Conjunto José Maria de Melo - Tabuleiro dos Martins - Maceió - AL - CEP 57081- 445 (fono_aline@hotmail.com).

**Fonoaudiólogo. Médico Especialista em Otorrinolaringologia pela Associação Brasileira de Otorrinolaringologia e Cirurgia Cérvico-Facial e Associação Médica Brasileira (AMB); Professor Auxiliar da Faculdade de Fonoaudiologia de Alagoas - Uncisal

***Fonoaudióloga. Especialização em Motricidade Oral pela Universidade Federal de Pernambuco. Professora Auxiliar da Faculdade de Fonoaudiologia de Alagoas.

*****Fonoaudiólogo. Mestre em Biofísica pela Universidade Federal de Pernambuco. Professor Assistente da Disciplina Física Acústica e

Psicoacústica da Faculdade de Fonoaudiologia de Alagoas.

*****Pesquisa Realizada na Universidade Estadual de Ciências da Saúde de Alagoas.

Artigo de Pesquisa

Artigo Submetido a Avaliação por Pares

Conflito de Interesse: não

Recebido em 23.08.2006.

Revisado em 31.05.2007; 23.07.2007.

Aceito para Publicação em 23.07.2007.

Referenciar este material como:

OLIVEIRA, A. C.; ANJOS, C. A. L.; SILVA, E. H. A. A.; MENEZES, P. L. Indicative factors of early facial aging in mouth breathing 53 adults (original title: Aspectos indicativos de envelhecimento facial precoce em respiradores orais adultos). Pró-Fono Revista de Atualização Científica, Barueri (SP), v. 19, n. 3, p. 305-312, jul.-set. 2007.

\begin{abstract}
Background: early facial aging in mouth breathing adults. Aim: to verify the presence of indicative factors of early facial aging and to characterize the measurements of the projection of the nasogeniane fold to the tragus and of the face width in mouth and nose breathing adults. Method: aspects of early facial aging were observed in 60 individuals (presence of dark circles and wrinkles under the eyes, mentual wrinkles and mentual ridges). Measurements of the projection of the nasogeniane fold to the tragus and of the face width (distance between the buccinators) were taken using a digital caliper. Later, the volunteers were submitted to speech-language evaluations (anamneses and orofacial myofuntional assessment) and to an otolaryngology inspection in order to establish the diagnosis of mouth breathing (anamneses, clinical evaluation and video laryngoscopy). The obtained data were analyzed according to descriptive statistics and to the following statistic tests: Kolmogorov-Smirnov, Shapiro-Wilk, Quisquare, Mann-Withney and the T-Student test for independent variables. Differences were considered significant when the $\mathrm{p}$ value was inferior to .05 and the accepted beta error was of .1. Results: the research sample consisted only of female volunteers. For the research group (mouth breathers) the age average was of $22.04 \pm 2.25$ years and, for the control group (nose breathers) the age average was of $21.94 \pm 2.03$ years. The presence of a high percentage of indicative factors of early facial aging was observed for the group of mouth breathers when compared to the group of nose breathers. Greater differences between the projections of the nasogenianos ridges in right and left side of the face was also observed for the group of mouth breathers. However, higher values of face widths were observed for the nose breathing individuals, configuring a discreetly more widened face in the cheek region. Conclusions: in the present study there was a higher indication of early facial aging for the group of mouth breathers. Key Words: Aging; Face; Mouth Breathing.
\end{abstract}

\section{Resumo}

Tema: envelhecimento facial precoce em respiradores orais adultos. Objetivo: verificar a presença de aspectos indicativos de envelhecimento facial precoce e caracterizar morfometricamente as medidas da projeção do sulco nasogeniano ao tragus e da largura facial (distância entre os bucinadores) em respiradores orais e nasais adultos. Método: foi realizada, em 60 indivíduos, observação de aspectos indicativos de envelhecimento facial precoce (presença de olheiras, rugas embaixo dos olhos, rugas mentuais e sulco mentual). Em seguida, foram tomadas medidas da projeção do sulco nasogeniano ao tragus e da largura facial (distância entre os bucinadores) utilizando-se paquímetro eletrônico digital. Posteriormente, os voluntários foram submetidos às avaliações fonoaudiológica (anamnese e avaliação miofuncional orofacial) e otorrinolaringológica (anamnese, avaliação clínica e exame de videonasofaringolaringoscopia) para diagnóstico da respiração oral. Após os dados obtidos serem caracterizados com a utilização de técnicas de estatística descritiva, aplicou-se os testes de aderência de Kolmogorov-Smirnov e Shapiro-Wilk e os testes de hipótese Qui-quadrado, Mann-Withney e o teste $\mathrm{T}$ de Student para variáveis independentes. As diferenças foram consideradas significativas para valores de p menores que 0,05 e o erro beta admitido foi de 0,1 . Resultados: a amostra foi composta apenas por voluntários do sexo feminino. Verificou-se, no grupo teste (respiradores orais), média de idade de 22,04 \pm 2,25 anos e, no grupo controle (respiradores nasais), 21,94 $\pm 2,03$ anos. Observou-se, no grupo de respiradores orais, um percentual mais elevado da presença de aspectos indicativos de envelhecimento facial precoce quando comparado aos respiradores nasais, bem como maiores diferenças entre as projeções dos sulcos nasogenianos nas hemifaces direita e esquerda. Entretanto, foram observados maiores valores de largura facial nos respiradores nasais, configurando faces discretamente mais alargadas na região das bochechas. Conclusão: no presente estudo foram observados maiores indícios de envelhecimento facial precoce no grupo de respiradores orais.

Palavras-Chave: Envelhecimento; Face; Respiração Bucal. 


\section{Introduction}

Nasal breathing, which is natural and elementary from birth, provides favorable conditions for the adequate growth and development of hard and soft orofacial tissue, promoting facial harmony and balance (Ribeiro et al, 2002. Carvalho, 2003).

Mouth breathing is an adaptive function that occurs when there is an impediment to nasal breathing. It is defined as a syndrome which causes countless disturbances for the individual and can be either organic or functional in origin. The former occurs in the case of a mechanical obstacle to breathing and the latter where the airways are permeable.

Organic respiratory insufficiency can be caused by mechanical obstructions in the internal nasal cavities, conchae, rhinopharynx or the oral cavity. Among the organic factors, the most common are: hypertrophy of the pharyngeal and palatinal tonsils, deviation of the nasal septum, hypertrophy of the turbinal bones, chronic pharyngitis and allergic rhinitis.

Casanova (2004) and Tessitore (2004) cite the causes of functional oral respiration as flaccidness of the orofacial musculature, hyperfunction of the elevating muscles of the jaw, a short or incompetent upper lip and an enlarged tongue.

The mouth breather may display innumerous characteristics, among these: craniofacial growth with vertical predominance, reduction of the tonus, hyperfunction of the lips and cheeks, retracted or shortened upper lip and lower lip with eversion or obstruction between the teeth; shadows under the eyes (infraorbital cyanosis) with asymmetry in eye positioning; sleep alteration, insomnia and frequent fatigue and hypercontraction of the mentual muscle (Tallgren et al., 1998; Vig, 1998; Di Francesco, 1999; Marins, 2001; Junqueira et al., 2002; Paulo and Conceição, 2003; Burger et al., 2004; Tessitore, 2004; Mekhitarian et al., 2005; Rodrigues et al., 2005; Lessa et al., 2005).

Parolo and Bianchini (2000) and Tessitore (2004) further mention the presence of facial asymmetry alterations in expressive facial mimicry, illconfigured or tense nasogenal sulcus and reduced facial tonus.

The reduction of tonus in the facial muscles, especially the major and minor buccinators and zygomas, form what is known as facial flaccidity, causing low facial resistance to tension, with a 'collapsed face' appearance and producing premature aging (Jardini, 2001; Jardini, 2002; Tasca, 2002).
There are three factors capable of causing alterations in the tonus of facial musculature: the aging process; alterations in the orofacial functions and respiratory and postural irregularities. Therefore, facial flaccidity is not exclusively related to the loss of muscle tonus during the aging process and can be present in children, young people and adults, in addition to the elderly. (Oliveira e Vieira, 1999; Tasca, 2002).

The buccinator is a mimic muscle responsible for the facial flaccidity present in mouth breathers (Marchesan, 1993) and directly related to the signs of aging. This muscle confers the facial image of the individual since it is situated in the centre of each facial hemisphere, proportioning balance and symmetry (Méndez et al., 2004; Jardini, 2005; Jardini et al., 2006).

Evidence of premature ageing is more obvious in the face than other areas of the body, since it is the location of numerous muscles with different functions, favoring premature wrinkling (Pierotti, 2004). These muscles, especially those responsible for facial expression, do not have facial sheaths, a characteristic of skeletal muscles, and are situated just below the skin, forming a layer which is almost unique. In this way, their contraction moves the cutis, provoking depressions characterized by lines or creases perpendicular to the direction of the muscle fibers which, in time and with the repetition of these movements, form wrinkles (Madeira, 2003).

Wrinkles, grooves or creases in the skin, are caused by a reduction in the deepest fat layers, the size of cells that make up the dermis and their hydric content, and by alterations in collagen and the elastic fibers (Tasca, 2002).

Among the determining factors for the appearance of wrinkles are: genetics; heredity; sun exposure; smoking or cigarette smoke; environmental toxins; inadequate diet (primarily a lack of vitamins A, C, E and folic acid) with a high percentage of fat/salt; low hydration; excessive consumption of alcohol; stress; sleep deprivation, as well as the natural aging process (Perricone, 2001; Velasco et al., 2004).

Besides these elements, the repetitive movements made by these individuals in the realization of stomatognathic functions can cause the appearance of these expression wrinkles. When these functions are balanced, the repetition of these movements can be inoffensive for a certain period, creating only transitory wrinkles. However, when performed inadequately, for a prolonged period 
and with abusive use of the musculature, these movements can prematurely shape what are known as permanent expression wrinkles (Franco e Scattone, 2002; Takacs et al., 2002; Madeira, 2003; Ulson, 2003).

According to Ulson (2003) and Franco (2005), nasogenal folds are caused by the exaggerated contraction of the facial muscles when performing stomatognathic functions, fatigue and lack of sleep. These sleep disturbances, very common among mouth breathers, also cause dark circles and wrinkles under the eyes.

The practice of phonoaudiology in facial esthetics can prevent or reduce the appearance of expression wrinkles through the balance of stomatognathic functions and the relaxation of facial musculature. With this professional intervention, we observe the reduction of nasogenal folds, dark shadows, flaccidness of the cheeks and wrinkles under the eyes, as well as a relaxed, rested and serene face with more defined lips and a change in posture (Franco e Scattone, 2002; Takacs et al., 2002; Ulson, 2003; Pierotti, 2004).

Thus, as a result of the countless alterations caused by mouth breathing and considering its influence on facial ageing, the main objective of this study was to verify the existence of indicators of premature facial ageing with the specific aim of the morphometric characterization of the degree of prominence of the nasogenal sulcus to the tragus and facial width (distance between the buccinators) in mouth and nasal breathers.

\section{Method}

The protocol of this study is based on current legislation, Resolution No 196/96, of the National Health Council, of the Ministry of Health, for studies with human beings and was approved by the Research Ethics Committee of the Alagoas State University of Health Sciences - UNCISAL, protocol n ${ }^{\circ} 453$.

\section{Sample}

The sample consisted of 60 individuals, allocated to two groups according to the presence/ absence of mouth breathing. The control group was composed of 23 individuals with diagnosis of nasal breathing through phonoaudiology and otohinolaryngology; and the test group of 37 volunteers, diagnosed as mouth breathers.
The following inclusion criteria were used: a) age between 20 and 30 years; b) normal weight [Body Mass Index (BMI) index between 18.5 and 25, WHO - World Health Organization Obesity (1998)]. Exclusion criteria were: a) plastic surgery and/or other methods of softening facial wrinkles; b) neurological problems; c) neuromuscular disorders d) prior (up to six months previously) speech therapy treatment in vocal motricity; e) albinism or black skin; f) presence of three or more dental imperfections; with only extraction or congenital agenesis of the third upper and lower molars accepted, as long as these were not adjacent, in order to avoid impairment of the musculature and mucous of the cheeks.

Procedures for data collection

Initially, a selection questionnaire was applied, followed by the reading of the "Consent Form", verbally explained and then signed by the subjects who agreed to participate in this study.

Thereafter, an observation was performed of indicators of premature facial ageing (presence of dark shadows, wrinkles beneath the eyes, mentual folds and wrinkles) and faces were photographed (front, left and right profiles) using an Olympus Digital Camera C - 4040 (CCD sensor with 4,1 megapixels; optic zoom 3xb 38mm - 114mm; 12x total precision zoom, of these $3 \mathrm{x}$ optical and $4 \mathrm{x}$ digital)

Facial measurements were then obtained using a Vonder electronic Digital Pachymeter, with a resolution of $0.01 \mathrm{~mm} / 0.005$ " and precision of $150 \mathrm{~mm} / 6 "$. In order to measure the prominence of the nasogenal sulcus to the tragus, the methodology adopted by Paes (2004) was used, as shown in Figures 1 and 2. Furthermore, the distance was measured between the buccinator muscles (facial width) as proposed by Jardini (2005) (see Figures 3 and 4). In the anthropometric analysis of the face, three measurements per subject were taken, in order to achieve an average value.

Volunteers then underwent an otorhinolaryngological and speech-audiological evaluation for the diagnosis of mouth breathing. The case history and speech therapy evaluation (orofacial myofunction) were performed by a speech therapist at the Laboratory of Instrumentation and Acoustics - LIA at UNCISAL. The otorhinolaryngological analysis was performed by an otorhinolaryngologist at the Otorhinolaryngology Clinic at the same institution and was made up of the case history, clinical evaluation and the nasopharingoscopy. 


\section{Data Analysis}

Since the objective of this study was not to generalize the findings, calculations of sample size were not performed. However, 30 volunteers were selected, by group, to increase the probability of the use of parametric tests (Doria Filho, 2003). Additionally, adherence tests by KolmogorovSmirnov and Shapiro-Wilk were applied, to verify the normality of the sample.

The data were tabulated and processed to a microcomputer, version SPSS 13.0. Data is reported

FIGURE 1. Prominence of the nasogenal sulcus measurement.

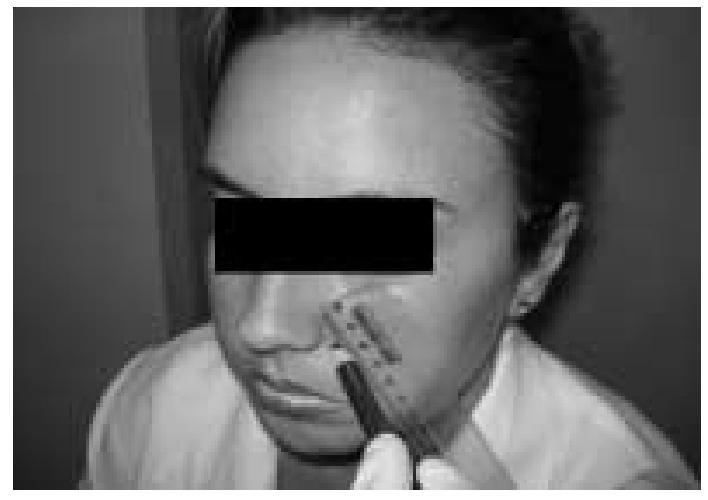

FIGURE 3. Localization of the buccinator muscles point.

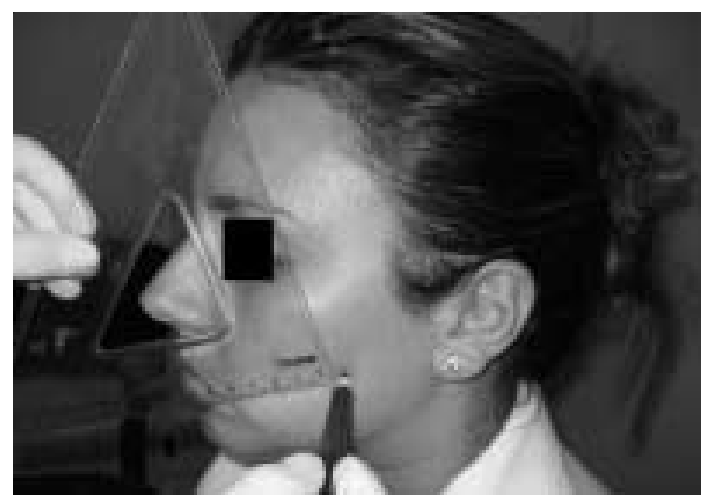

using tables and charts of the means, standard deviations and percentages.

After characterizing the data using techniques of statistical description, we applied the chi-square or Mann-Whitney tests to compare variables without normal distribution, depending on whether these were nominal or ordinal. The Student's t-test was used to verify the differences between the variables with normal distribution. Amounts were considered significant for $\mathrm{p}$ less than $0.05(\mathrm{p}<0.05)$. The beta error value allowed was 0.1 .

FIGURE 2. Prominence of the nasogenal sulcus to the tragus measurement.

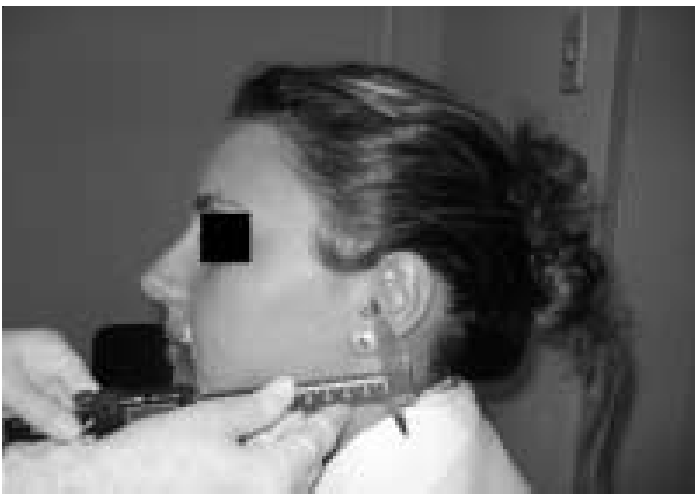

FIGURE 4. Measurement between the buccinator muscles (facial width)

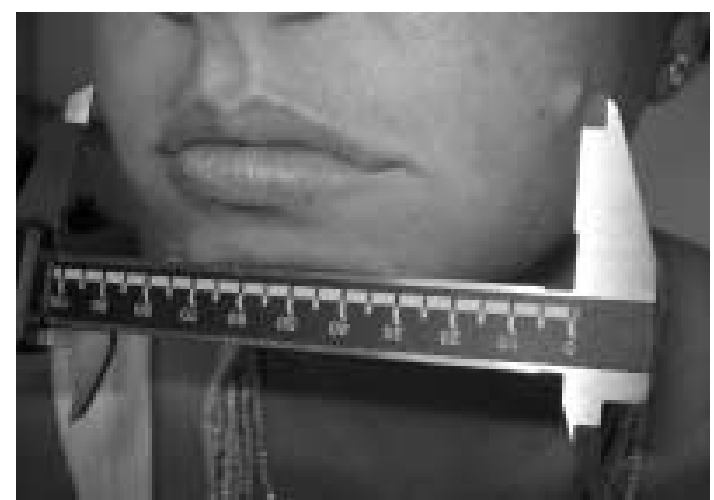




\section{Results}

The sample studied consisted of 60 women volunteers, 23 (38.3\%) from the control group (nasal breathers), and 37 (61.66\%) from the test group (mouth breathers). The test group had an age range of 20 to 30 years, mean age of 22.04 and standard deviation of 2.25. The control group, with varying ages between 20 and 28 years, had a mean age of 21.94 years and standard deviation of 2.03 .

The normality of the samples was observed using the Shapiro-Wilk and Kolmogorov-Smirnov tests; however normal distribution was only verified in the following variables: quantity of indicators of premature facial ageing, facial width (distance between the buccinators) and the measurements of the prominence of the nasogenal sulcus to the tragus (test group). Consequently, parametric tests were used for these variables and non-parametric tests for the non-homogenic variables.

GRAPH 1. Indicators of premature facial ageing.

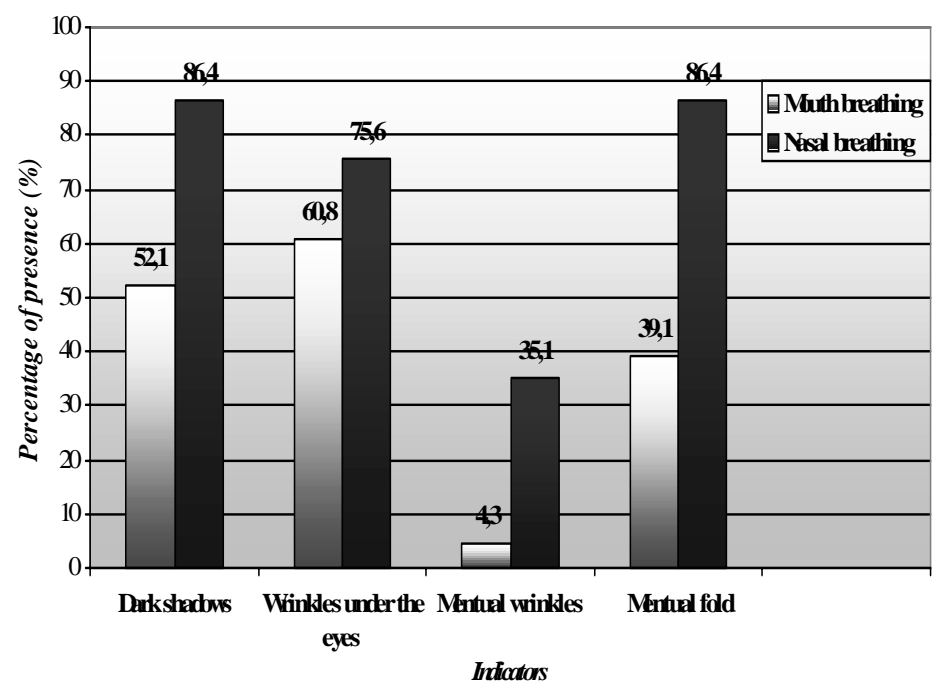

TABLE 1. Presence of Indicators of premature facial ageing.

\begin{tabular}{l|l|l}
\hline Chi-Square test & \multicolumn{2}{|c}{} \\
\hline & Significance $(\mathrm{p})$ \\
\cline { 2 - 3 } Dark shadows & 0,835 & Mouth breathing \\
Wrinkles under the eyes & 0,297 & 0,002 \\
Mentual fold & 0,297 & $<0,001$ \\
\hline
\end{tabular}

The study showed a higher percentage of indicators of premature facial ageing in the mouth breathing group than in nasal breathers, as shown in graph 1.

The chi-square test was used to analyze which signs of premature facial ageing could actually be considered present in each group. Thus, it can be confirmed that for the mouth breathing group, dark shadows, wrinkles under the eyes and mentual folds are significantly apparent. While for the group of nasal breathers, none of these signs are significantly present. (table 1).

The chi-square test also showed that the nasal breathers do not display mentual wrinkles, with a value of $\mathrm{p}$ less than 0.001 . However, among the mouth breathers, no significant evidence of these wrinkles was found $(\mathrm{p}=0,071)$.

The test group also had a higher average amount of premature facial ageing indicators per person (3.43) than the control group (2.17). Student's t-test confirmed the difference between the two means, and found a significant $\mathrm{p}$ value of 0.03 .

Analysis of the distance between the buccinators (facial width) showed that the control group had a mean facial width of $107.96 \mathrm{~mm}$ whereas for the test group it was $106.48 \mathrm{~mm}$, meaning that the nasal breathers had faces which were slightly wider in the cheek area. However, student's t-test showed no significant difference between the two groups $(\mathrm{p}=0.111)$.

As can be observed in table 2, mean dimensions of prominence of the nasogenal sulcus to the tragus were larger in nasal breathers, on the left and right facial hemispheres, than in the mouth breathers. To obtain this figure, the student's t-test was applied in the group of mouth breathers $(p=0.747)$, while the Mann-Withney Test was used for the nasal breathers $(\mathrm{P}=0.362)$, with no statistically significant differences observed.

In relation to the measurements of the prominence of the nasogenal sulcus to the tragus, there were higher differences in value (modulation) between the right and left sides in the test group $($ mean $=5.15 \mathrm{~mm})$ than in the control group $($ mean $=$ $3.87 \mathrm{~mm}$ ). When comparing the two groups using the Mann-Whithney test, no significant differences were found $(\mathrm{p}=0.167)$. 


\section{Discussion}

Discussion of the methods

The decision was taken to use only women in this study, in order to avoid interference in the results caused by differences between the sexes in relation to the quantity of muscle fibers and the natural process of facial ageing. (Jardini, 2005).

In relation to age, the sample should consist of subjects between the ages of 20 and 30 years, as this age range can be fitted into a single group with regard to neuromuscular appearance, and also because the first signs of premature facial ageing appear from the age of 30 (Pierotti, 2004; Jardini, 2005). Thus, we aimed at discarding any aspects relative to the natural ageing process.

Indicators of premature facial ageing were considered to be facial expression wrinkles, pronounced nasogenal folds and facial flaccidity. However, among these wrinkles, only those which displayed a relation to mouth breathing, such as wrinkles under the eyes and mentual wrinkles, were analyzed (Pierotti, 2004; Franco, 2005).

In addition, the presence of dark shadows was confirmed, since sleep alterations are very frequent in mouth breathers (Di Francesco, 1999; Mitre, 2003; Burger et al., 2004; Mekhitarian et al., 2005). These wrinkles form a face with a tired appearance, which is considered by Franco (2005) as a sign of facial ageing.

In relation to indicators of facial ageing, the presence of mentual folds was also examined. These are considered to be gravitational wrinkles and are directly related to eversion of the lower lip and the intense contraction of the mentual muscle, common characteristics in mouth breathers. (Ulson, 2003; Franco, 2005).

For analysis of facial morphology, anthropometry was also used. This offers countless advantages, its simplicity making it an important clinical instrument, and provides reference data on normality for a large variety of facial measurements. However, some factors can interfere in the accuracy of these measurements, such as: distances lower than 2 or $3 \mathrm{~cm}$, subjective location of distances to be measured and the taking of only one measurement (Budai et al., 2003).

Consequently, in order to avoid any interference, the measurements followed the methodology used in previous investigations (Paes, 2004; Jardini, 2005), where points of easily
TABLE 2. Dimensions of prominence of the nasogenal sulcus to the tragus in mouth and nasal breathing $(\mathrm{mm})$.

\begin{tabular}{ccccc}
\hline & \multicolumn{2}{c}{ Nasal breathing } & \multicolumn{2}{c}{ Mouth breathing } \\
\cline { 2 - 5 } & Right side & Left side & Right side & Left side \\
\cline { 2 - 5 } Mean & 96,92 & 98,64 & 96,53 & 95,64 \\
$\begin{array}{c}\text { Standard } \\
\text { deviation }\end{array}$ & 5,96 & 5,80 & 7,62 & 5,99 \\
\hline
\end{tabular}

visualized demarcation were determined, providing more reliable measurements; three measurements were taken to confirm the distances obtained (Quintal et al., 2004).

Discussion of the results

A higher percentage of indicators of premature facial ageing were confirmed in the group of mouth breathers, as well as a greater quantity of these signs per individual. However, the findings were not mentioned in the literature consulted.

The increase in tonus of the mentual muscle in mouth breathers due to the attempt to promote lip closure is well documented in the literature (Tallgren et al., 1998; Vig, 1998; Di Francesco, 1999; Marins, 2001; Paulo e Conceição, 2003; Tessitore, 2004; Rodrigues et al., 2005). However, no significant presence of mentual wrinkles was noted in these individuals.

The lower values of facial width in the mouth breathing group was unexpected, since according to Oliveira and Vieira (1999), facial flaccidness often occurs in this group. Individuals with facial flaccidness should therefore have larger distances between the buccinators than the subjects without this alteration (Jardini, 2005).

Higher dimensions of prominence of the nasogenal sulcus to the tragus were observed in the control group than in the test group. However, larger differences were observed, between the right and left sides, in the group of mouth breathers, making higher facial disproportion evident in these individuals. These findings corroborate, in part, the study conducted by Paes (2004), where reductions in the differences in anthropometric measurements of these grooves were observed, 
when both sides of the face were compared after speech therapy intervention in the pursuance of facial esthetics, with improvement in the symmetry and harmony of the face.

\section{Conclusion}

In the present study it was observed indicators of premature facial ageing in the group of mouth breathers when compared with the group of nasal breathers. It was observed more advanced stages of presence of dark shadows, wrinkles beneath the eyes and mentual folds. In the mouth breathers it was observed faces a little bit more widened in the region of the cheeks and higher facial disproportion.

\section{References}

ABRANTES, C. T.; BRAGA, I. P.; SILVA, H. J. D. A. Alterações posturais nos respiradores orais. J. Bras. Fonoaudiol., Curitiba, v. 3, n. 12, p. 233-236, jul.-set. 2002.

BUDAI, M.; FARKAS, L. G.; TOMPSON, B.; KATIC, M.; FORREST, C. R. Relation between anthropometric and cephalometric measurements and proportions of the face of healthy young whith adult men and women. $J$. Craniofac. Surg., Philadelphia, v. 14, n. 2, p. 154-161, mar. 2003.

BURGER, R. C. P.; CAIXETA, E. C.; DI NINNO, C. Q. M. S. A relação entre a apnéia do sono, ronco e respiração oral. R. Cefac., São Paulo, v. 6, n. 3, p. 266-271, jul.-set. 2004.

CARVALHO, G. D. de. S.O.S. Respirador bucal: uma visão funcional e clínica da amamentação. São Paulo: Lovise, 2003.

CASANOVA, D. A família e os hábitos orais viciosos na infância. J. Bras. Fonoaudiol. Curitiba, v. 1, n. 5, p. 4453, out.-dez. 2000.

DI FRANCESCO, R. C. Respirador bucal: a visão do otorrinolaringologista. J. Bras. Otorrinolaringol., São Paulo, v. 1, n. 1, p. 56-60, jan. 1999.

DI FRANCESCO, R.; PASSENOTI, B.; MINITI, A. Respiração oral na criança: repercussões diferentes de acordo com o diagnóstico. R. Bras. Otorrinolaringol., São Paulo, v. 70, n. 5, p. 665-670, set.-out. 2004.
DORIA FILHO, U. Introdução à bioestatística. 7. ed. São Paulo: Elsevier, 2003.

FRANCO, M. Z.; SCATTONE, L. Fonoaudiologia e dermatologia: um trabalho conjunto e pioneiro na suavização das rugas de expressão facial. Fono Atual., São Paulo, v. 5, n. 22, p. 1-4, out.-dez. 2002.

FRANCO, M. Z. Fonoaudiologia e estética. In: LOPES FILHO, O. Tratado de Fonoaudiologia. 2. ed. São Paulo: Tecmedd, 2005. cap. 46, p. 799-817.

JARDINI, R. S. R. Uso do exercitador facial: um estudo preliminar para fortalecer os músculos faciais. Pró-Fono R. Atual. Cient., Barueri, v. 13, n. 1, p. 83-89, abr.-jun. 2001.

JARDINI, R. S. R. Avaliação eletromiográfica do músculo bucinador flácido usando o exercitador facial. Pró-Fono R. Atual. Cient., Barueri, v. 14, n. 3, p. 331-342, set.-dez. 2002.

JARDINI, R. S. R. Avaliação facial a partir da relação eletromiográfica e antropométrica do músculo bucinador. R. Soc. Bras. Fonoaudiol., Curitiba, v. 10, n. 3, p. 161167, out.-dez. 2005.

JARDINI, R. S. R.; RUIZ, L. S. R.; MOYSÉS, M. A. A. Electromyographic analysis of the masseter and buccinator muscles with the Pró-fono facial exerciser use in bruxers. 
J. Craniomandib. Pract., Chattanooga, v. 24, n. 1, p. 2937, jan.-mar. 2006.

JUNQUEIRA, P. A. S.; DI FRANCESCO, R. C.; TEREZZA, P.; FIRZZARINI, R.; FARIA, M. E. Alterações funcionais do sistema estomatognático pré e pós adenoamigdalectomia. Pró-Fono R. Atual. Cient., Barueri, v. 14, n. 1, p. 17-22, jan.-mar. 2002.

LESSA, F. C. R.; ENOKI, C.; FERES, M. F. N.; VALERA, F. C. P.; LiMA, W. T. A.; MATSUMOTO, M. A. N. Influência do padrão respiratório na morfologia craniofacial. R. Bras. Otorrinolaringol., São Paulo, v. 71, n. 2, p. 156-160, mar.-abr. 2005.

MADEIRA, M. C. Anatomia da face: bases anátomofuncionais para a prática odontológica. 4. ed. São Paulo: Sarvier, 2003. 236 p.

MARINS, R. G. Síndrome do respirador bucal e modificações posturais em crianças e adolescentes: a importância da fisioterapia na equipe interdisciplinar. R. Fisioter. Mov., Rio de Janeiro, v. 14, n. 1, p. 45-52, abr.-set. 2001.

MARQUESAN, I. Q. Motricidade oral. São Paulo: Pancast, 1993. p. 52-57.

MEKHITARIAN NETO, L.; FAVA, A. S.; LOPES, H. C.; STAMM, A. Estudo epidemiológico das alterações estruturais da cavidade nasal associadas à síndrome da apnéia e hipopnéia obstrutiva do sono (SAHOS). R. Bras. Otorrinolaringol., São Paulo, v. 71, n. 4, p. 464-466. jul.ago. 2005 .

MÉNDEZ, M. F.; HERNÁNDEZ, I.; ROSSAND, G. Estructuración y estandarización de la antropometría facial em función de proporciones. Intern. J. Cosmetic Med. Surg., Toronto, v. 6, n. 3, p. 10-14, abr. 2004.

MITRE, E. I. Respiração. In: MITRE, E. I.; MARCHESAN, I. Q.; ZORZI, J. L. Conhecimentos essenciais para atender bem a inter-relação otorrinolaringologia e fonoaudiologia. São José dos Campos: Pulso, 2003. cap. 20, p. 81-85, Coleção Cefac.

MOTONAGA, S. M.; BERTE, L. C.; ANSELMO-LIMA, W. T. Respiração bucal: causas e alterações no sistema estomatognático. J. Bras. Fonoaudiol., Curitiba, v. 66, n. 4, p. 56-60, jul.-ago. 2000.

OLIVEIRA, M. O.; VIEIRA, M. M. Influência da respiração bucal sobre a profundidade do palato. Pró-Fono R. Atual. Cient., Barueri, v. 1, n. 1, p. 13-20, jan.-mar. 1999.

PAES, M. C. N. M. Estética facial e voz: uma nova interface. 2004. 67 f. Monografia (Especialização em Motricidade Orofacial) - Departamento de Cirurgia, Universidade Federal de Pernambuco, Recife.

PAROLO, A. M. F.; BIANCHINI, E. M. G. Pacientes portadores de respiração bucal: uma abordagem fonoaudiológica. R. Dent. Press Ortodon. Ortop. Fac. Maringá, v. 5, n. 2, p. 76-81, mar.-abr. 2000.
PAUlO, C. B.; CONCEIÇÃO, C. A. Sintomatologia do respirador oral. $R$. Cefac., São Paulo, v. 5, n. 3, p. 219-222, jul.-set. 2003.

PERRICONE, N. O fim das rugas. Rio de Janeiro: Campus, 2001 .

PIEROTTI, S. Atuação fonoaudiológica na estética facial. In: COMITE DE MOTRICIDADE OROFACIAL DA SOC. BRAS. FONOAUDIOL. Motricidade orofacial: como atuam os especialistas. São Paulo: Pulso, 2004. cap. 35, p. 281287.

QUINTAL, M.; TESSITORE, A.; PASCHOAL, J. R.; PFEILSTICKER, L. N. Quantificação da paralisia facial com paquímetro digital. R. Cefac. São Paulo, v. 6, n. 2, p. 170176, abr.-jun. 2004.

RIBEIRO, F.; BIANCONI, C. C.; MESQUITA, M. C. M.; ASSENCIO-FERREIRA, V. J. Respiração oral: alterações oclusais e hábitos orais. R. Cefac., São Paulo, v. 4, n. 3, p. 187-190, set.-dez. 2002.

RODRIGUES, H. O. S.; FARIA, S. R.; PAULA, F. S. G.; MOTTA, A. R. Ocorrência de respiração oral e alterações miofuncionais orofaciais em sujeitos em tratamento ortodôntico. R. Cefac., São Paulo, v. 7, n. 3, p. 356-362, jul.-set. 2005.

TAKACS, A. P; VALDRIGHI, V; ASSENCIO-FERREIRA, V. J. Fonoaudiologia e estética: unidas a favor da beleza facial. R. Cefac., São Paulo, v. 4, n. 2, p. 111-116, abr.-jun. 2002.

TALLGREN, A.; CHRISTIANSEN, R. L.; ASH, M. M.; MILLER, R. L. Effects of a myofunctional appliance on orofacial muscle activity and structures. Angle Orthod., v. 68, n. 3, p. 249-258, abr. 1998.

TASCA, S. M. T. Programa de aprimoramento muscular em fonoaudiologia estética facial (PAMFEF). Barueri: PróFono, 2002. 186 p.

TESSITORE, A. Alterações oromiofuncionais em respiradores orais. In: FERREIRA, L. P.; BEFI-LOPES, D. M.; LIMONGI, S. C. O. Tratado de Fonoaudiologia. São Paulo: Roca, 2004. cap. 23, p. 261-276.

ULSON, S. M. A. Estética facial: possibilidades da intervenção fonoaudiológica no diagnóstico e tratamento das rugas de expressão. In: MARCHESAN, I. Q; ZORZI, J. Tópicos em fonoaudiologia 2002/2003. Rio de Janeiro: Revinter, 2003. cap. 29 , p. $315-39$.

VELASCO, M. R. V.; OKUBO, F. R.; RIBEIRO, M. E.; STEINER, D.; BEDIN, V. Rejuvenescimento da pele por peeling químico: enfoque no peeling de fenol. Anais Bras. Dermatol., Rio de Janeiro, v. 79, n. 1. p. 80-96, jan.-fev. 2004.

VIG, K. W. L. Nasal obstruction and facial growth: The strength of evidence for clinical assumptions. Am. J. Orthodont. Dentofac. Orthop., Columbus, v. 113, n. 65, p. 603-611, jun. 1998 . 